\title{
Red Ties and Residential Schools
}


This page intentionally left blank 


\section{Red Ties and Residential Schools}

Indigenous Siberians in a

Post-Soviet State

Alexia Bloch

$\overline{\text { PENN }}$

University of Pennsylvania Press

Philadelphia 
Copyright $\odot 2004$ University of Pennsylvania Press

All rights reserved

$\begin{array}{llllllllll}10 & 9 & 8 & 7 & 6 & 5 & 4 & 3 & 2 & 1\end{array}$

Published by

University of Pennsylvania Press

Philadelphia, Pennsylvania 19104

Library of Congress Cataloging-in-Publication Data

Bloch, Alexia.

Red ties and residential schools : indigenous Siberians in a post-Soviet state / Alexia Bloch.

p. $\mathrm{cm}$.

Includes bibliographical references and index.

ISBN 0-8122-3759-5 (cloth : alk. paper)

1. Evenki (Asian people)-Education-Russia (Federation)—çvenkiæskiæ avtonomnyæ okrug-History. 2. Ethnology-Russia (Federation)—çenkiæskiæ avtonomnyæ okrug. I. Title.

LA1394.E84B56 2003

$371.829941-\mathrm{dc} 21$

2003056123 
To those who continue to dream of utopia

... and for Mira Rubina 
This page intentionally left blank 